\title{
How Much Are Your Trade Secrets Worth? Here's How to Figure It Out
}

\author{
James Hoffman (New Mexico State University) \\ Bradley Ewing (Texas Tech University) \\ Mark A. Thompson (Augusta University)
}

KEYWORDS: Entrepreneurship, Ethics, Legal,

Valuation.

Intellectual property -- a legal concept that refers to the product or fruits of human creativity for which exclusive rights are recognized -- is often critical to the success of both product- and service-based entrepreneurial ventures. One type of intellectual property is a trade secret: a practice, process, formula, design or a compilation of information, which is not generally known or reasonably obtainable, that a business can use to gain an operationally based competitive advantage. Trade secrets and other types of intellectual property are essential to economic growth and development. While much has been written about the laws that protect such intellectual property, few have researched how entrepreneurial ventures can calculate the economic and financial damages when their ideas are stolen and their competitive advantage disappears. We have developed a way to do that.

\section{Introduction}

The Commission on the Theft of American Intellectual Property estimates that the theft of trade secrets costs the U.S. economy $\$ 300$ billion a year. According to the International Chamber of Commerce, federal cases of trade secret theft doubled between 1995 and 2004 and will double again by 2017 .

Large, well-established companies such as Starwood Hotels, GE, Boeing, DuPont and others have recently been victims of economic espionage. Valuable trade secrets about military aircraft, new medicines, improved corn seeds, chemical formulas and many other innovations have been stolen. But newer, entrepreneurrun ventures are no less vulnerable. Part of the U.S. national plan to reduce economic espionage involving trade secrets includes encouraging private industry, both large businesses and small, to adopt best practices.
This paper shows how a company can take inventory and determine which trade secrets the business possesses, then calculate their value -- a critical step for keeping trade secrets confidential and secure. Once they've identified their trade secret assets and calculated the value of each one, businesses must ensure they are adequately protecting that value.

Here is an overview of the four different methods that we recommend to quantify the economic and financial consequences of stolen or misappropriated trade secrets:

Lost Profits. These are typically measured by determining the number of additional sales the firm would have made and the incremental profits from those sales if the trade secrets or intellectual property had not been improperly acquired or used.

Unjust Enrichment Calculations. This uses the same methods as applied to lost profits and are subject to the same issues. Calculating these economic and financial consequences should account for the non-infringing elements of sales, the economic environment in which the firms operate, the market structure in which the firms operate, the time period of advantage, the demand for the product or service, and costs associated with providing the product or service.

Reasonable Royalty. Many economists prefer this approach to estimate the economic and financial consequences from misappropriated trade secrets. According to Goldscheider (1996, section D), "Damages in trade secrets cases falls within the discretion of the district court. In many cases, it could provide the most appropriate methodology, and the fact that the 'reasonable royalty' approach has been so widely used and accepted in patent cases provides 
confidence, for its employment in the field of trade secrets damages."

Transaction-Specific Reasonable Royalty. This looks at the specific revenues, costs and profits for the sales of the product or service in question. This approach is an economic analysis of trade secret misappropriations that utilizes a transaction-specific reasonable royalty based on specific criteria, which are discussed in the paper in more detail.

Below is a more in-depth look at how businesses can calculate and quantify the economic and financial impact of their trade secrets; the ideas behind the methods; and the economics involved. It is important from both an economics and entrepreneurship perspective, because it provides a theoretical basis for why trade secrets and other types of intellectual property can increase an entrepreneurial firm's competitive advantage; and why businesses must be able to quantify the economic and financial consequences if these assets are stolen. Following these discussions, we also offer some prescriptions that can help entrepreneurial ventures protect themselves. This paper extends and expands on the work of Triest \& Vis (2007), who presented an approach for valuing patents on production process improvements.

\section{Innovation and Intellectual Property}

Innovation has been viewed as an essential component of competitiveness, embedded in the organizational structures, processes, products and services within a firm (Gunday et al., 2011). Often times organizational innovations result in intellectual property. A major threat to entrepreneurial ventures is the loss of that intellectual property that has provided the firm with one or more operationally based competitive advantages. Here is a case study that illustrates the problem:

In a recent court case, Hilton was accused of pilfering proprietary information about Starwood's successful W hotels in order to build its own luxury boutique chain (Starwood Hotels \& Resorts Worldwide v. Hilton Hotels Corporation, No. 09-cv03862 [S.D.N.Y. April 16, 2009]).

Based in White Plains, N.Y., Starwood sued in federal court in Manhattan for misappropriation of trade secrets, accusing Hilton of using stolen materials to quickly launch its new brand. The lawsuit alleged that during his final days at Starwood, Ross Klein used a personal laptop to download thousands of pages of company data, including demographic studies, financial reports and other records related to plans for $W$ hotels. These documents helped Hilton launch a lifestyle brand similar to Starwood's W chain, called Denizen. The lawsuit also alleged that 44 executives at the highest levels of Hilton had read the stolen materials before launching Denizen.

After the lawsuit was filed in April 2009, Hilton ditched the Denizen brand and fired Klein after 11 months on the job. Hilton also disclosed that it had received a grand jury subpoena requesting any Starwood materials in its possession that may have come from Klein or another Starwood employee, Amar Lalvani.

As part of a settlement agreement, Hilton agreed to stay out of that market segment until January 2013. Hilton also agreed to let an outside monitor make sure it returns any stolen files and other documents to Starwood. Additional terms of the settlement were confidential, but the New York Times (December 22, 2010) reported that Hilton also agreed to pay Starwood $\$ 75$ million.

Criminal charges were not filed.

Although the importance of trade secrets and other types of intellectual property has been at the forefront of economics literature for decades, the primary focus has been on issues related to growth, development and international trade (Nordhaus, 1969; Mansfield, Mark, and Samuel, 1981; Deardorff, 1982; Mansfield, 1985; Besen and Raskind, 1991). There is also abundant literature pertaining to the development of laws to protect intellectual property and the associated regulatory issues pertaining to compliance and enforcement (Dasgupta and Stiglitz, 1980; McFetridge and Rafiquzzaman, 1986; Milgrim, 1989; Landes and Posner, 1987, 1989; Klemperer, 1990; Maurer and Zugelder, 2000; Pagnattaro, 2012). Additionally, several articles in the literature have examined intellectual property from a business ethics perspective (Resnik, 2003; Gewertz and Amado, 2004; Lehman, 2006; Budde-Sung, 2012).

Only a few studies have examined issues related to the economic and financial consequences that can arise when intellectual property is violated. Examples of this research include Triest \& Vis (2007) who put forth an 
approach for valuing patents on cost-reducing production process improvements from the viewpoint of the patent-holding firm. Another example is a study by Kylaheiko et al. (2011), which examined the mechanisms that make it possible to first create value from knowledge assets; second to protect the value created by using different protection mechanisms; and third how to share the value created among the innovator, imitators and partners. Most recently, Kogan et al., (2013) addressed pricing and protection investment strategies to regain the profits affected by software piracy.

The lack of entrepreneurship-related research pertaining to the economic and financial consequences entrepreneurial firms face when trade secrets have been misappropriated is surprising, given that over the past 30 years trade secret litigation in federal courts has grown exponentially while federal litigation has decreased overall. One reason for this may be due to the confidential nature of the circumstances and outcomes surrounding intellectual property cases. Because of this confidential nature, it can be difficult to assess the value of trade secrets today or compare their current value to their value in years past. In spite of these difficulties, economists do value intangible assets, including trades secrets and other types of intellectual property (Triest and Vis, 2007; Almeling, 2012). In order to shed additional light on this important topic, the current paper provides some needed background on the basis for measuring the economic and financial consequences that may occur when intellectual property rights (specifically trade secrets) are violated, specifically for entrepreneurial firms.

The remainder of this paper is organized as follows. First, it reviews literature pertaining to how trade secrets and intellectual property have been defined in the literature and how their importance to entrepreneurial firms is supported by the resource-based view (RBV) of the firm. Next, we discuss the different methods that can be used to quantify consequences, the ideas behind the methods, and an overview of the economics involved in these issues. We end with some recommendations to help companies protect themselves, and some conclusions that can be drawn from the paper.

\section{Theory}

Intellectual property is a legal concept that refers to the product or fruits of human creativity for which exclusive rights are recognized. Intellectual property covers literature, songs, advertising slogans and new inventions. The term intellectual property is usually thought of as comprising four separate, but often overlapping, legal fields: trade secrets, copyrights, patents, and trademarks (Bouchoux, 2013). The focus of the current paper is on trade secrets.

A trade secret is a practice, process, formula, design or compilation of information, which is not generally known or reasonably obtainable, that a business can use to gain a competitive advantage. Trade secrets are kept secret using reasonable security measures and include such things as manufacturing processes, computer programs, customer lists and blueprints for machines (McJohn, 2009).

In determining whether information constitutes a trade secret, courts will consider: (1) how much effort or money the claimant expended in developing or acquiring the information; (2) whether the information gives the claimant a commercial, competitive advantage over others who do not know it; (3) how difficult it would be for others to properly acquire or duplicate the information; (4) whether the claimant has taken reasonable measures to ensure that the information remains secret; (5) who within the claimant's company knows the information; and (6) how widely the information is known outside the claimant's business (Barrett, 2012)

Over the years, trade secrets and other types of intellectual property have become increasingly essential to economic growth and development. The increasing importance of trade secrets has unleashed a boom in litigation, media reports, legislation and scholarly attention. Almeling (2012) identified seven factors behind this phenomenon, including: (1) the shifting calculus between whether to pursue patent or trade secret protection; (2) an increase in international threats; (3) trade secrets' flexible definition; (4) the widespread adoption of the Uniform Trade Secrets Act; (5) the rising value of intellectual property, of which trade secrets are a part; (6) a mobile workforce; and (7) digital technology.

\section{Trade Secrets: A Resource-Based View of the Firm Perspective}

The importance of trade secrets and intellectual property to businesses is supported by the resourcebased view (RBV) and also by the knowledge-based view of the firm. The resource-based view (RBV) of the 
firm has been a common interest for management researchers since it was presented as early as 1959 by Edith Penrose. She argued that a firm, in addition to being an administrative unit, is also a collection of productive resources, the disposal of which is determined by administrative decisions. Wernerfelt (1984) coined the term and defined resources as "those assets that are tied semi-permanently to the firm."

Most scholars consider Barney's resource theory as the modern RBV of the firm. Barney (1991) suggests that there can be heterogeneity among firms that allow some of them to create a competitive advantage, and when this advantage is difficult for competitors to imitate or purchase, superior performance becomes sustainable. Based on RBV, a firm's resources should include all assets, whether tangible or intangible -- including organizational processes, knowledge, firm attributes, information and a positive culture. These resources are controlled by the firm and they enable the firm to conceive of and implement strategies that improve its efficiency and effectiveness (Barney, 1991).

The RBV view also suggests that knowledge is a type of resource (Grant, 1996). Significance of knowledge is widely recognized under the knowledge-based view of the firm as the most strategically significant resource that can increase an organization's competitive advantage (Armbrecht et al., 2001; Goh, 2002; Kylaheiko et al., 2011). Trade secrets and other types of intellectual property are types of knowledge that can increase an organization's competitive advantage. When they are inappropriately acquired (e.g., stolen) or utilized in an uncompensated or agreed-upon manner, then financial damage is done to the firm. In these situations, it is critical to be able to quantify the economic and financial consequences. In the section below, we explain the different methods that can be used to quantify economic and financial consequences, the ideas behind the methods, and an overview of the economics involved in these issues.

\section{Calculation of Economic and Financial Consequences when Trade Secrets are Violated}

Economists generally recognize the gains from misappropriation of trade secrets as including the elimination of initial investment in time and resources and the reduction in time it takes to bring a product or service to the market. Under the Head Start theory, economists recognize the time costs (to design, develop, test, etc.) and the research and development (R\&D) costs that may be avoided. Moreover, the time period considered in an economic analysis lasts until some disclosure destroys the secrecy and/or until the defendant could have independently developed and sold the product/service. In terms of initial investment (R\&D), an economic analysis considers such factors as, but not limited to:

- what portion of the trade secret may be in the public domain

- $\quad$ time to develop

- time to test

- labor costs

- $\quad$ investment in physical capital (e.g., equipment, property, etc.)

- $\quad$ other expenses

In assessing damages, economists consider a number of factors affecting firm performance and business activity within the context of the economic environment and market structure in which the firms under consideration operate. In cases involving misappropriation of trade secrets, economists generally consider economic and financial consequences in the form of those resulting from the proprietor's loss (e.g., lost profits), damages compensating the proprietor for the infringer's gain (e.g., unjust enrichment), limited to the infringer's gain attributable to the misappropriated trade secrets, and, in lieu of lost profits or defendant's unjust enrichment, economists often measure economic and financial consequences based on reasonable royalties (Learning Curve Toys, Inc. v. PlayWood Toys, Inc. 342 F.3d 714 (7th Cir. 2003)). Any calculations of economic and financial consequences that combine the plaintiff's loss and the infringer's gain should avoid double counting or duplication.

\section{Lost Profits}

Lost profits are typically measured by determining the number of additional sales the plaintiff would have made if the defendant had not acted improperly, and the plaintiff's incremental profits on these sales. Incremental profits consist of the revenue the plaintiff would have made on the additional sales, less the incremental costs that the plaintiff would have incurred in making the sales. Economists have come to consider, among other things, what are known as the Panduit[1] factors when 
determining whether or not lost profits from misappropriation of trade secrets should be calculated or, perhaps, another method is more appropriate. These factors are (Kerr and Parakash-Canjels, 2003, p. 88):

- the existence of demand for the patented technology

- $\quad$ the absence of non-infringing substitutes

- $\quad$ the patent owner having adequate production, marketing and distribution capacity to make the additional sales

- the claimant's ability to estimate the amount of lost profits in a reasonable or non-speculative manner

In computing lost profits, an economic analysis typically considers, but is not limited to, the following factors:

- market structure

- demand for the product or service (for the individual firms as well as the industry or market)

- $\quad$ apportionment

- $\quad$ costs (e.g., proper treatment of variable costs, etc.)

- $\quad$ time period (including Head Start or period of advantage)

Relating to market structure and demand, an economic analysis considers whether or not the plaintiff would have made all of the infringing company's sales or only some portion of those sales.

The economist must determine the market structure that best characterizes the market in which the firms in question have operated in (as well as other firms), particularly as it pertains to the product and/or services being examined. Market structure is often described in terms of the degree of competition ranging from the monopoly at one end of the spectrum to perfect competition on the other.

A monopoly is a market structure characterized by a single seller of a good or service with no close substitutes. The monopolist is a "price searcher" as the firm must search for the price and output combination that would maximize profit. This market structure has substantial barriers to entry.

In the case of a perfectly competitive market, there are many buyers and sellers of essentially the same product. A number of other features characterize the perfectly competitive market such as: perfect information as to price, availability, quality, etc., as well as easy entry and exit into the market (i.e., there are no meaningful barriers to entry and exit). In this market environment, firms are viewed as "price-takers;" that is, they may sell their product only at the market (e.g., industry) price and have no real way in which to influence the price that customers would pay for their good or service. Consequently, firms determine their production strategies, taking the market price as given. Of course, few perfectly competitive markets actually exist, though some commodity markets may come close. In practice, it is the degree to which a market resembles perfect competition that is important and which factors, if any, violate the strict definition of perfect competition.

According to Hirschey (2003), several key factors determine the level of competition, with two key conditions being "the number and relative size of buyers and sellers, and the extent to which the product is standardized. These factors, in turn, are influenced by the nature of the produce and production systems, the scope of potential entry, and buyer characteristics." (p. 380). Two important types of imperfectly competitive markets are monopolistic competition and oligopoly.

A monopolistically competitive market has many suppliers, each of which offers a slightly differentiated product/service (or mix of features and/or intangibles). This market structure or economic environment has firms which compete on "nonprice" items such as "goodwill," customer relationships, geographic or market focus, advertising, and reputation. In this type of market structure, firms attempt to acquire or maintain a sustainable competitive advantage.[2]

An oligopoly market structure is characterized by a few firms whose price and output decisions are interdependent. A few large firms typically dominate the market place, and entry into the industry is difficult or very costly. A good deal of strategic behavior and interaction is observed and the market is highly competitive. Products or services may be homogeneous or distinct, and information regarding price, quality, and costs is often difficult for buyers to obtain.

The economic environment is a determinant of how individual firms may perform with respect to changes in industry-wide and macroeconomic events. Failure to 
properly recognize and account for the market structure and economic environment in which the firms operate will produce biased and/or inaccurate estimates of lost profits as important factors related to industry performance, demand, market share and positioning, competitive advantage, "goodwill", strategic behavior, etc. contribute to and play a critical role in the determination of profits and firm performance.

The issue of apportionment relates to whether or not all, some, or none, of the sales are due to the infringing element, that is, the portion of the (total) sale attributable to the trade secret. Economists refer to characteristics or features of a product that customers expect to obtain when purchasing an item as the "order qualifiers," that is, features that are required for the customer to seriously consider the product for purchase. Economists refer to features or characteristics of a product that produce the sale (e.g., over a competing product that satisfies the qualifier's condition) as "order winners." The order winner features may be tangible or intangible (e.g., customer relationships have been established, reputation effects, etc.). Features added to the product beyond the infringing elements that qualify as "order winners" can be expected to significantly contribute to the sale and should be apportioned more weight accordingly.

Costs should be properly accounted for (e.g., all variable costs be recognized in the calculation for incremental profits). The period of time it would have taken the infringing company to develop its own version of the infringing element (i.e., the trade secret) and how much it would have cost to do so should be determined and considered. Failure to properly account for apportionment, costs and time issues will produce biased and/or inaccurate estimates of these damages.

Economists may incorporate information pertaining to which trade secret/infringing elements are involved in the product or service in question, the relative "ease" in which a firm might "design around" the infringing elements and whether or not only some of the components, but not all, of the product or service may have been misappropriated trade secrets. Moreover, the time to design, develop and/or acquire the infringing elements as well as associated costs may be useful information.

With respect to whether or not the lost profits approach is appropriate, economists typically consider the
Panduit factors. In each case, a determination must be made as to whether or not there exists a sufficient demand for the technology (i.e., infringing elements) and whether or not there are likely and/or probably noninfringing substitutes in existence.[3] Another consideration is whether or not the firm would have had adequate production, marketing and distribution capacity to make the additional sales.

Generally, the above stated factors (i.e., market structure, demand, apportionment, costs, and time period, and possibly others) are important for the establishment of economic and financial consequences. To the extent that these factors are ignored or inadequately addressed, estimates of lost profits and/or approach to calculating the amount of lost profits are fundamentally flawed and, therefore, the estimates lack economic relevance and are not economically meaningful.

The measurement of a plaintiff's lost profits was addressed in Mineral Deposits, Ltd. v.Zigan, 773 P.2d 606, 608-09 (Colo.App. 1988), where the Colorado Court of Appeals affirmed an award of damages for the plaintiff's lost profits based on their profit margins and what the gross amount of their receipts would have been had it sold the goods.

In this case, the Defendants (Theodore Zigan, Rite Form Concrete, Inc., Stephen Zbikowski, and Camax Consulting, Inc.) appeal the judgment of the trial court holding them jointly and severally liable to the plaintiff, Mineral Deposits Limited, for misappropriation of trade secrets and fraud. The plaintiff is an Australian corporation engaged in developing and manufacturing mining equipment. One of the products developed by plaintiff was the Reichert Spiral Concentrator, a device for recovering gold particles from sand and gravel. The Reichert spiral has received a patent in Australia and, before the events at issue here occurred, had applied for a patent in the U.S.

In October 1983, defendant Zigan contacted the plaintiff's sales representative and stated that he was interested in purchasing up to 200 spirals for use in his gravel pit. The sales representative agreed to lend Zigan a Reichert spiral for the purpose of testing the product's efficiency. After Zigan received the spiral, he removed the label that indicated that patent applications were pending and gave the spiral to defendant Zbikowski. Zbikowski then cut the spiral into 
pieces, made molds of the components, and proceeded to manufacture copies of the spiral.

Upon inspection of the spirals produced by Zbikowski, Zigan realized that Zbikowski was unable to duplicate the interior lining of plaintiff's spiral. Zigan then contacted plaintiff and obtained information about the equipment and processes used to coat the interior of plaintiff's spiral. Using this information, Zigan purchased the necessary equipment, and Zbikowski resumed production.

In January 1984, plaintiff contacted Zigan and demanded that he either pay for the spiral or return it. Zigan agreed to buy the spiral, and the plaintiff sent Zigan an invoice stating that the spiral was to be returned if payment was not made within seven days. After Zigan failed to make the requested payment, the plaintiff discovered that Zigan and Zbikowski were producing copies of plaintiff's spiral. The plaintiff immediately demanded the return of its spiral. Zigan refused but offered to pay for the spiral. The plaintiff refused to accept Zigan's payment, and instead instituted this action.

As mentioned above, the Colorado Court of Appeals affirmed an award of damages for the plaintiff's lost profits based on the plaintiff's profit margins and what the gross amount of the plaintiff's receipts would have been had it sold the goods. When calculating damages the trial court took into consideration that the defendants produced 170 spirals that were either used by defendants or sold to others. The trial court determined plaintiff's damages by multiplying the percentage of profit that the plaintiff would receive from the sale of an individual spiral by the total amount that the plaintiff would have received from the sale of 170 spirals.

Of course, it may be that the necessary information and data are not available and/or the economic and financial consequences are not logically calculable. In this situation, the Lost Profits method is deemed inappropriate. Economists generally try to avoid being excessively speculative when computing lost profits.

\section{Unjust Enrichment}

Unjust enrichment calculations generally utilize the same methods as applied to lost profits and are subject to the same issues. The calculation of these economic and financial consequences should account for the noninfringing elements of sales, the economic environment in which the firms operate, the market structure in which the firms operate, the time period of advantage, the demand for the product or service, and costs associated with the provision of the product or service. An economic analysis of unjust enrichment should avoid duplication of damages already accounted for in lost profits.

To the extent that important factors are ignored or inadequately addressed (i.e., market structure, demand, apportionment, costs, and time period, and possibly others), estimates of unjust enrichment and the approach to calculating the amount of unjust enrichment are fundamentally flawed and, therefore, the estimates lack economic relevance and are not economically meaningful.

As with the case of Lost Profits, it may be that the necessary information and data are not available and/or the economic and financial consequences are not logically calculable. In this situation, the Unjust Enrichment method is deemed inappropriate. Economists generally try to avoid being excessively speculative when computing damages of this sort. Finally, even in situations in which these methods (i.e., Lost Profits and Unjust Enrichment) are deemed appropriate, a proper economic analysis would avoid double-counting damages.

\section{Reasonable Royalty}

In lieu of lost profits or unjust enrichment, economists often estimate economic and financial consequences in cases of misappropriation of trade secrets using the reasonable royalty approach. According to Goldscheider (1996, section D) "Damages in trade secrets cases falls within the discretion of the district court. In many cases, it could provide the most appropriate methodology, and the fact that the 'reasonable royalty' approach has been so widely used and accepted in patent cases provide confidence, for its employment in the field of trade secrets damages." Economists consider, but are not limited to, the following factors when performing an analysis using the reasonable royalty method:

1. Head Start, period of advantage 
2. The "Georgia-Pacific"[4] factors (and possibly others) such as
- non-infringing substitutes
- comparable licenses
- license parameters
- costs to licensor
- benefits to licensee
- bargaining outcome

Methods for calculating economic and financial consequences under the theory of reasonable royalty should take into account the economic environment in which the portion of the realized profit that is due to the infringing element is distinguished from the noninfringing elements. Further, reasonable royalty is calculated to take into account the manufacturing process, business risks, and other significant features or improvements added by the infringer. Generally, economists view intellectual property as something that may provide economic benefits when combined with other assets. Trade secrets (e.g., unpatented invention, formula, customer lists, news, etc.) that have value possess one or more of the following (Wise, 1996, p. 50):

- $\quad$ protection or creation of a strong market position

- $\quad$ economic advantage (e.g., reduced costs and time)

- $\quad$ barriers to competitive entry

Reasonable royalty attempts to isolate the benefits attributable to the intellectual property component (i.e., the infringing element) of the business activity.

In the case of Altavion, Inc. v. Konica Minolta Systems Laboratory (A134343) (May 8, 2014), the trial court based its damages award on the reasonable royalty measure of damages. In this case, there was a judgment for the plaintiff finding that the defendant had misappropriated the plaintiff's trade secrets regarding its digital stamping technology (DST), which was disclosed to the defendant during negotiations pursuant to a Non-Disclosure Agreement. Specifically it was affirmed that: 1) the plaintiff did not fail to adequately identify its trade secrets; 2) the trial court did not err in its identification of the misappropriated trade secrets; 3) ideas are protectable as trade secrets; 4) design concepts underlying plaintiff's DST constitute protectable "information;" 5) substantial evidence supports the trial court's finding that plaintiff's DST design concepts had independent economic value and the finding that the defendant misappropriated plaintiff's trade secrets; 6) did not err in awarding prejudgment interest; and 7) the defendant did not demonstrate that the trial court abused its discretion in basing its fee award on local hourly rates or shown the hourly rates employed by the trial court were unreasonable.

There are several ways in which reasonable royalty may be calculated. For instance, the " 25 percent rule" is sometimes used when there is not sufficient information as to the established or standard industry royalty rates, or when special circumstances are present that distinguish the present case from other cases in the industry. The 25 percent rule effectively assigns a split between the two parties in which the infringing company pays a "royalty" to the other company based upon the infringing company's performance. The method is predicated on a very broad and general observation of licensing and royalties in the overall economy and thus is not specific to individualized, uncommon, or unique transactions. The method involves simply multiplying operating profit by $25 \%$ and using the resulting amount as an estimate of damages. The rule is more effective and appropriate when substantial R\&D costs are involved and when a process technology is involved (Razgaitis, 1999; Hagelin, 2002, p. 353). The 25 percent rule is not necessarily adequate when the infringing element results in only a minor improvement or minimal head start or when the transaction is not common. An Industry standard is a market or comparable technology method that focuses on royalty rates in similar transactions (Megantz, 1996). According to Megantz, the industry standards method aims to make distinctions between important technologies and lesser or minor improvements; thus, this method may not fully recognize the particular situation, its uniqueness, and any strategic considerations associated with the transaction.

\section{Transaction-Specific Reasonable Royalty}

Absent industry standards, which attempt to be more specific than the 25 percent rule by relying on past experience, an economic analysis of the transactionspecific reasonable royalty may be justified. Economists generally rely on many factors especially those related to specific companies R\&D costs, head start, and the economics associated with the ability to design around. 
The "individualized" or transaction-specific approach to reasonable royalty would take into account the factors described above and the actual costs associated with time to develop and design, R\&D, and cost of production for the infringing elements in relation to (i.e., properly apportioned) the cost of the specific product/service and the resulting revenues from sales of the product/service, that is, the approach would be predicated on the economics involved.

An analysis of the economic circumstances surrounding the case in question, the market in which the firms operate, and the firms involved, may indicate that an appropriate method for calculating economic and financial consequences is to utilize a transactionspecific reasonable royalty approach as it relates to the specific revenues, costs and profits for the sales of the product or service in question. An economic analysis of trade secret misappropriations that utilizes a transactionspecific reasonable royalty would be based on the considerations and factors already outlined above with emphasis placed on isolating the value creating properties of the specific element in question. In particular, but not limited to, the reasonable royalty would account for the apportionment of costs and revenues attributable to the infringing elements in relation to the total revenue and profit, the time period (head start or period of advantage) and the ability of the infringing firm to "design around" the elements in question. The latter consideration would depend on the time and costs to develop, design, and put into effect substitutable non-infringing elements. Economic theory and analysis indicates that when it is a relatively low cost (i.e., "easy") to "design around" an element, the infringing company would pay only a modest royalty as anything higher would provide the company with an incentive to "design around" and not use or license the intellectual property or technology (i.e., trade secrets or elements in question). In some cases this reasonable royalty would be extremely minor in magnitude and any potential economic damages would be negligible.

According to economic theory and analysis, in order for the royalty to economically compensate the firm whose trade secrets were infringed upon, and assuming that the trade secrets were misappropriated, the royalty should approximate the R\&D time and expenses that the infringing firm would incur to independently develop the elements in question. Economic theory and analysis also indicates that an appropriate margin (or markup) may be required by the developing firm to compensate them for any lost opportunity cost associated with devoting resources to R\&D of the elements in question. An estimate of this margin may be obtained from financial statements and, for example, the simple arithmetic average of the incremental operating profit margin for the time period or years in question be approximated. Economic theory and analysis indicates that a reasonable royalty approach to calculate the economic and financial consequences can then be estimated.

\section{Protecting Yourself}

After identifying the business's trade secrets and determining their value, entrepreneurial firms should also look at their physical and technical security and strengthen it if necessary. Paper documents should be stored in a physical place where access is limited and closely monitored. Electronic documents must also be securely stored and closely guarded.

Entrepreneurial firms should also review and update their agreements with employees as well as other firms that may have access. Specifically, non-compete and confidentiality agreements should be used with employees, suppliers and others who may have access to trade secrets. They should be shared only with people who have an absolute need to know the trade secret to perform their duties.

Finally, entrepreneurial firms should strive to hire carefully and create a culture of compliance. No employee should leave the firm without a substantive and robust exit interview, especially if he or she had access to confidential and proprietary information. Conducting these types of exit interviews is especially important if an employee is leaving for a competitor and information gathered during these interviews can prove helpful to civil or criminal enforcement actions down the road (Elliott, 2007).

\section{Conclusions}

Overall, it is hoped that the current paper will provide entrepreneurs, economists, and legal scholars along with business and policy decision makers with additional insights pertaining to the quantification of the economic and financial consequences caused by the misappropriation of trade secrets and other types of intellectual property. It is also hoped that this paper will lead to future research on this important topic and aid 
entrepreneurs in protecting their trade secrets.

\section{References}

Almeling, D. (2012). Seven reasons why trade secrets are increasingly important. Berkeley Technology Law Journal 27(2), 1091 - 1117.

Altavion, Inc. v. Konica Minolta Systems Laboratory (A134343) (Cal. Ct. App. May 8, 2014)

Armbrecht, R., Chapas, R., Chappelow, C., Farris, G., Friga, P., Hartz, C., Mcllavine, E., Postle, S., and Whitwell, G. (2001). Knowledge management in research and development. Research Technology Management 44(4), 28-48.

Barney, J. (1991). Firm resources and sustained competitive advantage. Journal of Management 17(1), 99-120.

Barrett, M. (2012). Emanuel Law Outlines: Intellectual Property, Third Edition, Wolters Kluwer Law \& Business, New York, pp. 1-10.

Besen, S. and Raskind, L. (1991). An introduction to the law and economics of intellectual property. Journal of Economic Perspectives 5(1), 3-27.

Bouchoux, D. (2013). Intellectual property: The law of trademarks, copyrights, patents and trade secrets. Fourth Edition. Delmar Cengage Learning, Clinton Park, New York, p. 3.

Buddle-Sung, A. (2012). The invisible meets the intangible: Culture's impact on intellectual property protection. Journal of Business Ethics Published Online.

Dasgupta, P., and Stiglitz, J. (1980). Industrial structure and the nature of innovative activity. The Economic Journal 90, 266-293.

Deardorff, A. (1982). The general validity of the Heckscher-Ohlin Theorem. American Economic Review 72, 683-94.

Elliot, S. (2007). The threat from within: trade secret theft by employees. Nature Biotechnology 25, 293-295.

Gewertz, N., and Amado, R. (2004). Intellectual Property and the pharmaceutical industry: A moral crossroads between health and property. Journal of Business Ethics 55, 295-308.
Goh, S. (2002). Managing effective knowledge transfer: An integrative framework and some practice implications. Journal of Knowledge Management 6(1), 23-30.

Goldscheider, R. (1996). The employment of licensing expertise in the arena of intellectural property litigation. The Journal of Law and Technology 36, 159-201.

Grant, R. (1996). Toward a knowledge-based theory of the firm. Strategic Management Journal 17, 109-122.

Gunday, G., Gunduz, U., Kemal, K., and Lutfihak, A. (2011). Effects of innovation types on firm performance. International Journal of Production Economics 133(2), 662-676.

Hagelin, T. (2002). A new method to value intellectual property. Quarterly Journal of the American Intellectual Property Law Association30(3), 353-403.

Hirschey, M. (2003). Managerial Economics, 10th ed., Thomson-Southwestern, Mason Ohio.

Kylaheiko, K., Jantunen, A., Puumalainen, K., and Luukka, P. (2011). Value of knowledge-Technology strategies in different knowledge regimes. International Journal of Production Economics 131(1), 273-287.

Kerr, W. and Parakash-Canjels, G. (2003). Patent damages and royalty awards: The convergence of economics and law. les Nouvelles 38(2), 83-91.

Klemperer, P. (1990). How broad should the scope of patent protection be? RAND Journal of Economics 21, 113-130.

Kogan, K., Yaacov, O., and Perlman, Y. (2013). Containing piracy with product pricing, updating and protection investments. International Journal of Production Economics 144(2), 468-478.

Landes, W., and Posner, R. (1987). Trademark law: An economic perspective. Journal of Law \& Economics 30, 265-309.

Landes, W., and Posner, R. (1989). An economic analysis of copyright law. Journal of Legal Studies 18, 325-366.

Lattman, P. (2010, December 22). Hilton and Starwood settle dispute. New York Times, online. 
Learning Curve Toys, Inc. v. PlayWood Toys, Inc. 342 F.3d 714 (7th Cir. 2003).

Lehman, J. (2006). Intellectual property rights and Chinese tradition section: Philosophical Foundations. Journal of Business Ethics. 69: 1-9.

Mansfield, E., Mark, S., and Samuel, W. (1981). Imitation costs and patents: An empirical study. The Economic Journal 91(364), 907-918.

Mansfield, E. (1985). How rapidly does new industrial technology leak out? Journal of Industrial Economics 34(2), 217-223.

McFetridge, D., and Rafiquzzaman, M. (1986). The scope and duration of the patent right and the nature of research rivalry. Research in Law \& Economics 8, 91-129.

McJohn, S. (2009). Intellectual Property, 3rd edition, Aspen Publishers, New York, pp. 5-11.

Mauer, S., and Zugelder, M. (2000). Trade secret management in high technology: A legal review and research agenda. Journal of High Technology Management Research 11(2), 155-174.

Megantz, R. (1996). How to License Technology, John Wiley, New York.

Milgrim, R. (1989). On Trade Secrets, Matthew Bender, New York.

Mineral Deposits, Ltd. v. Zigan, 773 P.2d 606, 608-09 (Colo.App. 1988).

Nordhaus, W. (1969). Invention, Growth, and Welfare, A Theoretical Treatment of Technological Change, MIT Press, Cambridge, MA.

Pagnattaro, M. (2012). Preventing know-how from walking out the door in China: Protection of trade secrets. Business Horizons 55(4), 329-337.

Penrose, E. (1959). The Theory of the Growth of the Firm, John Wiley, New York.

Razgaitis, R. (1999). Early-State Technologies: Valuation and Pricing, John Wiley, New York.

Resnik, D. (2003). A pluaralistic account of intellectual property. Journal of Business Ethics 46: 319-335.
Starwood Hotels \& Resorts Worldwide v. Hilton Hotels Corporation, No. 09-cv03862 (S.D.N.Y. April 16, 2009).

Triest, S., and Vis, W. (2007). Valuing patents on costreducing technology: A case study. International Journal of Production Economics 105(1), 282-292.

Wernerfelt, B. (1984). Resource-based view of the firm: Ten years after. Strategic Management Journal 5(2), 171-180.

Wise, R. (1996). Valuation and Damage-Quantification Issues Relating to Intellectual Property. Faculty of Law, McGill University, Meredith Memorial Lectures X.

[1] Panduit Corporation v. Stahlin Brothers Fibre Works, 575 F.2d 1152, 197 USPQ726, 6th Cir. 1978.

[2] Competitive advantage is a unique ability to provide a product/service that the customer values.

[3] The issue of "design around" is discussed elsewhere in this paper and relates to the demand for the technology and the existence of non-infringing substitutes.

[4] Georgia-Pacific v. United States Plywood Corp., 318

F.Supp. 1116. (I.S.D.N.Y. 1970) 